\title{
THE ROLES OF JUDGES IN DEMOCRACIES: A REALISTIC VIEW
}

\begin{abstract}
What are the "obligations" of judges in democracies? An adequate answer requires us to be realistic both about democracies and about law. Realism about democracy demands that we recognize that electoral outcomes are largely, though not entirely, unrelated to concrete policy choices by elected representatives or to the policy preferences of voters, who typically follow their party based on "tribal" loyalties. The latter fact renders irrelevant the classic counter-majoritarian (or counter-democratic) worries about judicial review. Realism about law requires that we recognize that judges, especially on appellate courts, will inevitably have to render moral and political judgments in order to produce authoritative resolutions of disputes, one of the central functions of a legal system in any society. That means it is impossible to discuss the "obligations" of judges without regard to their actual moral and political views, as well as the moral and political ends we believe ought to be achieved.
\end{abstract}

Keywords: Judges; Democracy; Roles.

What should the role of a judge be in contemporary democracies? That is our topic, but it has two important component parts that we should examine separately: a judge's role and democracy. Let us begin with a few introductory words about the former.

On one sensible view, succinctly articulated by Leslie Green $(2016,323)$, judges "settle disputes by applying pre-existing standards." Pre-existing standards need not be codified, and they need not be legally authoritative, though most will be. The central thought is that a judge in a legal system assesses disputed conduct relative to a norm that (usually) pre-dates the conduct and thus was not created by the judge. Sometimes, of course, those denominated judges make retroactive decisions, holding actors accountable to standards that they never would have (or

\footnotetext{
${ }^{1}$ Karl N. Llewellyn Professor of Jurisprudence and Director of the Center for Law, Philosophy \& Human Values, University of Chicago. These thoughts crystallized in the course of a series of seminars on realist jurisprudence I presented at the École des Haute Études en Sciences Sociales in Paris in June 2019. I am grateful to Prof. Otto Pfersman for inviting me and for his contributions to the seminars, as well as those of the students. I was also helped by discussion with students in my fall 2019 graduate seminar on current issues in general jurisprudence at the University of Chicago. Finally, I am grateful to Joshua Fox, a PhD student at the University of Chicago, for outstanding research assistance. Email: bleiter@uchicago.edu.
} 
even could have) recognized at the time, and sometimes the judges themselves create the standard, but these are not the normal cases for the judicial role, though they may be among the most important roles: authoritative resolution of disputes is central to civic peace. In any case, let us call making decisions according to preexisting standards the Minimal Role of a judge.

Green (ibid., 334-335) proposes three further "obligations" of judges, following H.L.A. Hart:

(1) "Judges have an obligation to apply valid law in making rulings, and...to make correct findings of fact, to know what the law is, to keep their knowledge of the law up to date....";

(2) "Judges have an obligation to keep the law 'legally in good shape'" (quoting John Finnis, and meaning judges should resolve unclarity and conflicts);

(3) "Judges have obligations to regulate their own processes and the conduct in their courts, and to protect the rule of law and the integrity of their jurisdiction from those who would attack it...."

I shall call these the Minimal-Plus Roles. Probably judges should do all these things too, though no legal positivist, including Green, thinks that judges have a non-defeasible moral obligation to apply valid law (per \#1). The hard issues about the role of judges in democracies are three-fold: what are the obligations of judges in determining what the applicable pre-existing standards are and their meaning; when should judges not apply valid law, per their Minimal-Plus Role?; and what further "obligations" do judges have beyond the Minimal and Minimal-Plus roles?

In the realistic spirit suggested by my title, let me be clear at the start that "obligations" - understood as moral obligations-do not really exist ${ }^{2}$ : when we speak of moral "obligations" (or "rights" or "duties") we are expressing certain attitudes, often very intense and insistent attitudes, about what we feel other people should or should not do. ${ }^{3}$ Expressing such attitudes is central to human life: as Nietzsche ([1883] 1976, II.13) put it, "all of life is a dispute over taste and tasting," and there is value in distinguishing between the strength and character of different tastes, as talk of "obligation" nicely does. Like other people who are products of the post-Enlightenment, post-WWII consensus, my "tastes" run towards individual rights and freedom and the rule of law, in which judges can play a crucial role in constraining behavior by other state actors, since such institutional practices seem to enhance aggregate human well-being. ${ }^{4}$

\footnotetext{
2 Legal obligations, rights and duties do exist: they are certain kinds of social artifacts (like "money" and "stocks"), produced by legal systems, and whether or not they obtain depends on whether they satisfy the existence-conditions for such legal norms in that system (see Leiter 2018).

${ }^{3}$ See esp. Stevenson (1944).

${ }^{4}$ Talk of "taste" like the economists' talk of "preferences" runs the risk of flattening the important differences between our attitudes about what others ought to do. I "prefer" chocolate to vanilla,
} 
Not having illusions about obligation talk, however, is not simply a matter of philosophical fussiness: imagine if theorists who said judges have "obligations" to do X said, instead, judges are "required by God" to do X? Recognizing that the latter is false-God does not exist, and so, unsurprisingly, has no views about anything, let alone the obligations of judges-means it is possible to express contrary attitudes without violating any moral or rational norm. The conceptual and practical space is open for contrary recommendations. This is a more important point, I think, than is usually recognized in recent academic writing. Assumptions about what is the case exercise a powerful normative force on human behavior and thought-sometimes for very good reason, to be sure. For example, that it is the case that the door is closed and locked gives me a very powerful prudential reason not to try to march straight through the doorway. Let us call this the normativity of fact: that something is taken to be factual or real, to be the case, influences, sometimes quite profoundly, what people think is possible, permissible, and so on. ${ }^{5}$ Sometimes, as in the case of locked doors, that's a good thing, but other times, it is not. So when we deny, in a realistic spirit, that moral obligations are metaphysical facts, we are making both a true metaphysical claim (the ontology of the world includes no moral obligations ${ }^{6}$ even if it includes some locked doors) and, at the same time, we are defeating the normativity of fact where its normativity has no real justification. ${ }^{7}$

When humans speak of moral "obligations" they are speaking of what they really want or expect certain people to do, perhaps no matter what. This is certainly revealing about the feelings of those engaged in such talk, and perhaps also revealing about their social and economic circumstances: Nazis, for example, thought of their actions in terms of obligations, ${ }^{8}$ and this included judges-not surprising, since, as Hart argued a half-century ago ([1961] 2012, 116), where there is a legal system, judges take themselves to have obligations to apply the valid legal norms, even when others might reasonably deem them catastrophically wrong to feel that way. What this should remind us of is that talk of "obligation" is an important feature of human social existence, but it is also compatible with a radical revision of human attitudes and thus a different set of attitudes about what our "obligations" are. Suitably deflating the idea of "obligation" is important if we are to think clearly about the roles of judges: for example, even in cases where judges

but I do not simply "prefer" toleration to genocide: those who "prefer" vanilla are not my mortal enemies, those who "prefer" genocide are.

${ }^{5}$ This is related to what Marxists call "reification," where some contingent and optional practice is treated as natural and necessary.

${ }^{6}$ See Leiter (2001 and 2015a).

${ }^{7}$ Of course, "justification" itself is normative, but normativity has a "justification" in my deflated sense when it comports with instrumental desires like not walking into closed doors.

${ }^{8}$ See Pauler-Studer and Velleman (2015). 
"promise" through an oath of office to do certain things, it may be that they should sometimes act otherwise. ${ }^{9}$ We return to that issue, also, below.

So can we generalize about the "role of judges in democracies"? We can, though subject to some constraints, since judges and democracies seem to differ along various dimensions. For example, there are "civil service" judiciaries in which appointment and promotion depends on evaluation by other judges, as in Britain; there are "political" judiciaries in which appointment depends on political connections and affiliation, as in the United States; and there are mixed models in which, for example, purportedly "peer" evaluation of judges for appointment and promotion is, in fact, influenced by political partisanship (I am told Italy is such a case). Democracies differ in some respects as well: some are plutocracies masquerading as democracies (for example, the United States); some are incipient authoritarian societies masquerading as democracies (for example, Hungary and Poland); and some are more conventional representative democracies with all their pathologies of class conflicts and political personalities (for example, the current United Kingdom).

A serious discussion about the roles of judges in democracies has to be realistic both about judges and about democracies. It has to acknowledge what judges really do and how democracies actually function, and it has to be clear about what judges can do against those backgrounds. It also has to be explicit about our normative aspirations and ideals (and also whether judges can realize them). Normative aspirations and ideals tend to be inchoate and not wholly consistent, though in their broad outline in the present historical moment they are clear: no one needs a moral theory, after all, to know whether they are against racism or in favor of racial equality, against chattel slavery or in favor of human freedom, against cruelty or in favor of treating people in a dignified way, against human misery or in favor of human happiness. (The problem, after all, with academic friends of Jobbik in Hungary, the National Front in France, or Donald Trump in America is not that they failed to appreciate the correct moral theory! ${ }^{10}$ ) I suppose throughout that judges, like other regular post-Enlightenment folk, should try to promote human well-being on some reasonable understanding (the theoretical differences between extant accounts rarely matter given the constraints imposed in practice on judicial power) - though the role of judges in helping to promote human well-being will vary quite a bit depending on the nature of the judiciary and the nature of the democracy. My main topic will be the kinds of realistic variations and constraints on exercise of this judicial role. I thus hope this essay

\footnotetext{
${ }^{9}$ A promise might be thought to generate a moral obligation to fulfill certain functions in an institutional role. Whether those functions are obligations of the role is separate from the question whether there is a real moral obligation to fulfill those functions simply because of a promise.

${ }^{10}$ Remember that normative theory delivers no decisive conclusions about what ought to be done, being hostage to "intuitive" starting points that themselves can never be defended. See generally, Leiter (2016a).
} 
will be a contribution to the on-going revival of realist political and legal theory against the moralizing fantasies of so much academic writing about these matters over the last half-century. ${ }^{11}$ Theory will be important in what follows - for example, empirical theories about voting behavior in democracies, as well as philosophical claims about the nature of law - but normative theory will not be. ${ }^{12}$

I start with a realistic view of democracies, and then turn to judges.

\section{A REALISTIC VIEW OF DEMOCRACY}

Democracies typically have two features in common: individuals have the right to vote for some number of those who hold political power and they also enjoy rights to certain individual freedoms. So, on the one hand, democracies hold elections in which some significant portion of the citizenry can vote for some range of candidates or parties (perhaps two or three or four), the elections are fair and incumbents can actually be voted out of office: this is the crux of the democratic ideal that "the people rule." On the other hand, democracies also typically, in the post-World War II era, protect some range of individual rights-rights to expression, privacy, and fair legal process most prominently-though again to varying degrees. ${ }^{13}$ Call the combination of electoral rights and rights to individual freedom "Democratic Values." Debates about the role of judicial review of legislation in democracies typically focus on the electoral aspect, and how that is consistent with judicial invalidation of legislation when it violates individual rights: in the United States, this is called the "counter-majoritarian" difficulty (Bickel 1962), though in parliamentary systems, it could also be called the "counter-

${ }^{11}$ For examples of the realist revival, see Posner (1999 and 2008), Geuss (2008), perhaps Williams (2005), and also Leiter (2012 and 2015b).

${ }^{12}$ Realists deny the priority of theorizing about moral truth to theorizing about how political and legal actors should behave, that is, they deny that we should treat political and legal theory as simply "applied ethics," without regard to the strategic questions peculiar to each domain. The central idea is that realists "should theorize about the distinctive forces that shape real politics" and judicial behavior (Rossi and Sleat 2014, 689). Realism, in this sense, is partly about attention to feasibility constraints (ibid., 690-691), though not wholly. (An example of realist feasibility constraints in operation is the debate between the moralist Stephen Gardiner and the realist David Weisbach in Debating Climate Ethics (Gardiner and Weisbach 2016).) But feasibility does not exhaust the realist approach to questions about what political and legal actors should do. There are normative considerations peculiar to both the political and legal domains: in the former, stability and security; in the latter, authoritative resolution of disputes that arise in any human community. But realism in recent political theory is characterized by neglect of the characteristic of classical realism in Thucydides, Machiavelli, and Nietzsche, namely, attention to what human beings are really like. See Leiter (2019).

${ }^{13}$ The protection of the individual freedoms is typically dependent on allegiance to the family of "rule of law" virtues, such as an independent judiciary, the principle that no one is above the law, the requirement to treat like cases alike, the publicity of legal standards, etc. It is not wholly dependent-contra Lon Fuller and other anti-positivists-since the substantive content of the law matters crucially, even if all the other virtues are honored. 
democratic" difficulty, since judges, once again, defy the will of a democratic legislature, though less often a majoritarian one. ${ }^{14}$ A realistic view of democracy should help us see why this latter concern is without merit, and why the real question for judges who embrace "Democratic Values" should be whether laws really protect the individual rights that are equally central to Democratic Values. ${ }^{15}$

The reason we should disregard the supposed counter-majoritarian or counterdemocratic difficulty is because there is almost never a plausible sense in which the particular laws passed by a legislature represent the views of an electorate, whose will is then thwarted. That laws reflect the view of the electorate would be true only if two further claims were true:

(1) The majority of the legislature intended the legislation to achieve purpose $X$.

(2) The majority (or plurality) of people who elected the legislature (the "electorate") wanted them to pass legislation which achieved purpose X.

The first claim has been subjected to various kinds of critique by economists and public choice theorists, who emphasize that collective intentionality in a legislature is a fiction, and a misleading one. ${ }^{16}$ But the more serious problems arise for the second claim, which presupposes something doubtful: that law-makers are elected because of commitments to pass particular kinds of legislation to achieve particular goals. Even in its most plausible form, known as the "spatial theory of voting" in the empirical political science literature, it supposes only that people vote for the party that is closest (in ideological space, as it were) to their ideological "preferences." But even if voters really did that, this would rarely license the conclusion that any particular piece of legislation that achieved purpose $X$ reflects the will of the voters. There are, of course, the fundamental theoretical difficulties with this view due to Arrow's Theorem (Achen and Bartels 2016, 23-30), ${ }^{17}$ but even

\footnotetext{
${ }^{14}$ The United States Congress is not a majoritarian institution either as it happens-its Senate is obviously not, and its House of Representatives, due to gerrymandering, is not either. The United Kingdom is a special case, since the courts cannot invalidate acts of Parliament on grounds of violating individual rights, but they can declare them incompatible with such rights, and thus prompt a legislative reevaluation.

${ }^{15}$ I assume, with Mill among others, that protection of individual rights generally promotes human flourishing and well-being. Perhaps this is false, but as of now, we have no reason to think it is.

${ }^{16}$ See Easterbrook $(1983,547-548)$ and $(1994,68)$; but cf. Ekins (2012). But even the defenses of intention do not really establish the requisite level of specificity of intention that would make the counter-majoritarian difficulty meaningful.

${ }^{17}$ Achen and Bartels reprise, with new evidence, arguments first made by Elmer Schattschneider (1960). Spatial voting theorists, in turn, have produced new evidence in the last decade to try to resist the realist conclusions. An important example is Stephen A. Jessee (2009). The problem with this literature is that its results are compatible with the realist hypotheses about the role of group identity in driving party identification, and the way in which voters conform their views to the party leaders rather than the other way around. I acknowledge that the argument of the paper is hostage to the soundness of the realist picture, but since realism in every domain I know of international relations, political theory, legal theory, historical explanation-is always the most
} 
more worrisome for the spatial theory is the overwhelming evidence that voters do not have clear ideologies. For example, in the 1980s - the height of the reactionary Reagan Era in the United States, when the social welfare state was under sustained attack-nearly $65 \%$ of Americans thought the government was spending too little on "assistance to the poor," but at the same time only $25 \%$ thought too little was spent on "welfare" (ibid., 30), a term that had been demonized by Reagan, even though it means "assistance to the poor"! ${ }^{18}$ What this shows is that expressions of purported "ideology" by the population are sometimes nothing of the kind, unless by "ideology" one does not mean what voters actually believe about concrete policy questions!

This is surprising to university professors, of course, who are disproportionately "ideologues" in the sense defined by the American political scientist Philip Converse in 1964, namely, those who have well-defined views about policy questions (such that, e.g., they realize that "assistance to the poor" is the same as "welfare," and either favor or oppose both). In Converse's study, these "ideologues" were $3 \%$ of the population, while $85 \%$ of the voting population "seemed to think about parties and candidates in terms of group interests or the 'nature of the times' or in ways that conveyed 'no shred of policy significance whatever'" (Achen and Bartels 2016, 32). ${ }^{19}$ Ironically, academic interest in the United States in the "counter-majoritarian" difficulty about judicial review of legislation flourished precisely after the period studied by Professor Converse.

If the spatial theory of voting fares poorly in showing why we should worry about judicial invalidation of democratically enacted laws that violate individual rights, the alternatives fare even worse. The "retrospective theory" of democracy suggests that voters express their judgment of the past performance of those they vote for (or against). That sounds somewhat promising, but in fact voters primarily respond to economic events only in the several months preceding an election (ibid., 148-158) and, more importantly, they do not discriminate between events for which elected officials bear some plausible causal responsibility and those events which are basically natural disasters: floods, droughts, even shark attacks (on one occasion) have all influenced voters in past elections (118-135). ${ }^{20}$ Simply put: if

explanatorily successful approach, I am willing to rest my argument on the Achen and Bartels version.

${ }^{18}$ We don't know how clarification about the terms would have shifted preferences, of course, but it is easy to see how it could have gone either way: some of the anti-welfare folks would have realized that "assistance to the poor" was meant to incorporate all the putatively bad aspects of welfare; similarly, some of the pro-"assistance to the poor" folks might have been horrified to learn that what they favored really had the putatively bad aspects of welfare. And, of course, we can imagine the converse.

${ }^{19}$ See Kinder and Kalmoe (2017) for an updated and concurring investigation of ideological identificationin the American public.

${ }^{20}$ Achen and Bartels' shark attack claim has been challenged in Fowler and Hall (2018). The first half of Fowler and Hall is irrelevant, since it tests an hypothesis that Achen and Bartels do not 
voters are miserable in the months before an election, often regardless of the cause of the misery (122-137), ${ }^{21}$ they generally take out their unhappiness in their voting behavior. If there are reasons for judges committed to individual rights and human well-being to hesitate to invalidate legislation produced by such a process, those reasons can have nothing to do with the moral importance of democratic voting.

I should pause here to emphasize that there may well be other reasons for judges to hesitate.22 Most importantly, settled law creates settled expectations, and unsettling those have costs that judges must consider. In addition, and as we will return to below, invalidating legislation may affect the legitimacy of the courts, and

defend, namely, that shark attacks influence presidential elections. Achen and Bartels focus on a rather singular case-the multiple shark attacks in 1916 along the New Jersey coast, which attracted national and international attention, and which were utterly unprecedented. Their finding was that in the coastal counties closest to the site of the widely covered attacks, Woodrow Wilson's share of the vote declined markedly by comparison to both his 1912 results and his results in New Jersey counties farther removed. The relevant part of the Fowler and Hall critique centers on disputing choices by Achen and Bartels about the various comparison classes, and most of those critiques simply show that, if you redraw the comparison classes, the statistical effect on election outcomes of the shark attacks is reduced. The notion of "statistical significance" is epistemically vexed, to put it mildly, but what is missing from the Fowler and Hall critique is any serious attention to the question of "mechanism," that is, the causal processes by which a certain event $\mathrm{X}$ brought about an outcome $\mathrm{Y}$. Only with a plausible story about mechanism can we really rule out or in "statistically significant" or "statistically insignificant" correlations, since the P value of greater than 95\% is both arbitrary and largely meaningless (Colquhoun 2014). (The basic problem is that $95 \%$ confidence that an effect is not random compared to the null hypothesis does not guarantee it is a real effect (a real cause-effect relationship). What we need to know in addition is how good our test is for detecting real effects and how many real effects there are in the sample studied (the latter, of course, is hard to estimate). But consider: even with the standard $p=.05$ standard of statistical significance, if our measures only capture $80 \%$ of real effects, and real effects are only $10 \%$ of our sample, then one-third of our positive results will turn out to be false positives even with the standard P value. Cf. ibid., 4-5.) Achen and Bartels are aware of the need for a story about causal mechanisms (cf. their discussion of narratives at 138-142), and the shark attack case, while amusing and memorable, is only one small data point for their general hypothesis that voters are terrible at assigning causal responsibility for events that affect them adversely. If the underlying causal mechanism in their explanatory story is that ordinary voters have little understanding of causal responsibility, and yet adverse experiences influence their voting behavior, then they have a story about mechanism which Fowler and Hall lack.

${ }^{21}$ Caveat: sometimes voters need a narrative before assigning blame. Achen and Bartels discuss the case of the catastrophic Spanish influenza pandemic of 1918, which felled half a million Americans yet didn't translate to losses at the polls for incumbents: "[N]o thread of elite rhetoric or popular discourse seems to have suggested any attribution of responsibility to President Wilson or other public officials. As long as no one supplied a convincing argument that the government did control or should have controlled the spread of the pandemic or its horrific consequences, the pain of millions failed to have any electoral impact" (142).

${ }^{22}$ This is important to emphasize because many of my ultimate recommendations could apply to other official actors, albeit in slightly different terms. But there are aspects of institutional role and public expectations that caution restraint in all cases, including the judicial, but they vary with institutional role. 
it may also provoke backlash from other branches of government. But what is important to notice is that both these reasons for judicial restraint have nothing to do with the moral significance of how the population voted.

An alternative account of voting behavior recently defended most vigorously by self-described "realists" about democracy, Christopher Achen and Larry Bartels, does nothing to restore the moral importance of democratic voting. On their view, it is "group identity" that best explains voting behavior in democracies. ${ }^{23}$ By group identity, they mean the religious, racial, ethnic, occupational and cultural identities ${ }^{24}$ that are important to people: their "tribes" for short. On their "group theory of politics - the powerful tendency of people to form groups, the ensuing construction of 'us' and 'them,' and the powerful role of emotion rather than reason in directing group activity" - "group attachments are easily generated and profoundly felt" (Achen and Bartels 2016, 215). ${ }^{25}$ What Achen and Bartels argue is that the group identity largely explains the political party with which individuals identify, and we know that, as Professor Converse put it, "expressions of party identification were much more stable" over time than ideological convictions (ibid., 34). In other words, for most voters, their tribal loyalties drive party identification, and party identification then drives voting behavior. ${ }^{26}$

In some measure, popular commentary on the political process in America has registered this fact: we all know that African-Americans vote Democratic by overwhelming majorities, and that white men do not. But this also explains another important empirical finding, namely, that voters typically adjust their views to fit the ideology of their party (or its most visible representatives), rather than choosing parties based on how well they fit the voter's own views (ibid., 41-45, 258-264, chap. 10)! ${ }^{27}$ That fact helps make sense of the peculiarity of the Trump phenomenon in the United States, since he, in fact, rejected many staples of the "Republican brand" since the Reagan Revolution of the 1980s, though he won an overwhelming percentage of Republican voters in the end (I return to Trump below).

\footnotetext{
${ }^{23}$ Caveat: their evidence comes largely, but not exclusively, from the U.S.

24 The "cultural" identities are often geographically bounded: cf. Achen and Bartels (2016, chap. 9).

${ }^{25}$ Note that there is no reason that voting in accordance with one's group identity means voting in accordance with one's "interests" or well-being. Achen and Bartels do not claim otherwise. On any plausible view of human interests or well-being, voting in the pattern described by Achen and Bartels would stand in only an accidental relationship to the interests or well-being of the voters.

${ }^{26}$ Crucially, tribal loyalty does not drive party identification based on party ideology, except at the margins.

27 This was true in the case of Hitler too: for one of the most chilling discussions in the book, see pp. 314-316, which argues that the 1932 electoral success of the Nazis was almost entirely due to Protestant voters switching from the traditional Protestant parties (discredited by the crisis of capitalism beginning in 1929) to the National Socialists, while Catholics continued to vote as before. As Achen and Bartels note, the National Socialists did not emphasize anti-semitism at all in the 1932 campaign.
} 
Ideology of a party can matter at the margins, of course: at some point a particular "tribe" registers that a particular party is clearly friendly or hostile to the tribe. African-Americans in the United States supported Republicans from the end of the Civil War through the 1920s (at least when they could vote) since, after all, it was a Republican President who freed them from chattel slavery. (Unsurprisingly, a group freed from slavery noticed that fact.) Although Roosevelt began capturing a large share of the African-American vote in the 1930s, it was not until Truman desegregated the armed services in 1948 that a majority of African-Americans began to identify as Democrats (though Republicans still got a third or more of the African-American vote throughout the 1950s). But then it was a Democratic President, Lyndon Johnson, who ended de jure segregation in America in 1964, winning $94 \%$ of the African-American vote that year, and since then AfricanAmericans have voted overwhelmingly for Democrats (Bositis 2012, 9) (though, strikingly, as Achen and Bartels (2016, 246-258) document, Southern Whites were moving to the Republicans before the 1960s). But ideological considerations only go so far. African-Americans continued to support Democrats, including the Clintons (Bill and Hillary), despite the evidence that they were not very good for the African-American community. ${ }^{28}$ Of course, it will be fairly noted that the Clintons were always less hostile to interests of the African-American community than the Republicans, but even so, it hardly explains the failure of AfricanAmericans to rally to Senator Bernie Sanders, a Roosevelt New Dealer, in the 2016 Democratic primaries. Reflexive loyalties do seem to explain it.

Ironically, in the end, the absence of a member of their tribe on the ticket also helps explain the fact that African-American turnout was depressed in the 2016 Presidential election compared to elections when Obama was the candidate (Cohn 2016) $)^{29}$ : African-Americans, highly motivated to turn out to vote when one of their own was a candidate, were not nearly as enthusiastic about voting for a white woman and a white man in 2016. At the same time, some modest number of white working-class voters (not more than 100,000 in the three crucial states of Pennsylvania, Michigan, and Wisconsin), some of whom had supported Obama in 2012, flipped to Trump in 2016 (ibid.). ${ }^{30}$ This indicates that at least some highly salient parts of expressed ideology are relevant to some voters (Achens and Bartels do not deny this, but they are, conceptually, sloppy, which is typical of this literature-but they de facto acknowledge the point with their endless hedging about what "mostly" or "often" explains voting behavior). As the rabble-rousing filmmaker Michael Moore observed, when Trump came to Detroit and threatened auto executives that they had better not move their plants outside the U.S. or else, he did something no other candidate of the two ruling class parties in the U.S. had

\footnotetext{
28 See, e.g., Alexander (2012).

${ }^{29}$ Note that the decline in African-American turnout was consistent across states that had enacted new voter suppression rules and those that had not.

30 See also Cohn (2017).
} 
done in living memory (Moore 2016). "Free trade" has become a mantra of the ruling class and its intellectual apologists like Paul Krugman in America, but when a Presidential candidate repudiated it in the Mafioso terms in which Trump specializes, some number of voters took note, perhaps contributing to his victory in states with lots of industrial working-class voters like Pennsylvania, Michigan, and Ohio. And yet this result still confirms the main point of the realist theory of democracy. The working-class voters who flipped to Trump were largely union members, ${ }^{31}$ their loyalty to their class as defined by union membership (an increasingly uncommon loyalty in America) having an effect on their votes. If we are realists about democracy, then we need to acknowledge, as Achen and Bartels document, that tribal loyalties explain a frightening amount about voting behavior, while moral or ideological commitment generally does not, except in the extreme cases or among a small segment of the electorate. ${ }^{32}$

It is worth quoting at some length Achen and Bartels' own summary of their findings, since it makes clear the extent to which the popular, and theoretical, conceptions of democracy bear little relationship to any reality. In the summary that follows, they presuppose that party identification drives most voting behavior, and then focus on the case of the "pure" independent voters ${ }^{33}$ in the American context, those who do not lean to either the Democrats or Republicans:

While they, too, have group ties and social identities, they are often quite unclear about which groups "belong" in which party. Typically less-informed, they may fail to grasp what is at stake in the choice of one party or another, much less where their overall interests lie. Thus, they are often swept along by the familiarity of an incumbent, the charisma of a fresh challenger, or a sense that it is "time for a change," even when the government did not cause the current unsatisfactory situation and cannot greatly alter it. When the party balance is

\footnotetext{
${ }^{31}$ See, e.g., Bump (2016) and Weigel (2016).

32 Achen and Bartels are particularly critical of "highly idealistic models of participatory or deliberative democracy" (301). They write: "These models of democracy emphasize-indeed, they often simply assume - rationality, mutual consideration, and the patient exchange of publicly justified reasons for supporting specific policies. Thus, they rest on essentially the same unrealistic expectations about human nature embodied in the folk theory [of democracy]" (ibid.). Although I think Achen and Bartels are right to be dismissive of deliberative democracy theories, their reification of "human nature" cannot go unchallenged: none of the evidence supports the claim that the unrealistic character of deliberative democracy has anything to do with essential biological and psychological facts about human beings. The evidence they adduce only supports the view that under the conditions in which most people live, they have neither the time nor the interest to engage in deliberative democracy fantasies.

33 They here mean to exclude the "independents" who in fact, on further questioning, lean to one party or the other. They also mean to exclude quite clearly a category they don't mention, namely, "academic independents," who, as ideologues, have such well-defined views on policy questions that no existing party could be adequate to their excruciatingly "nuanced" conception of what should be done. As Nietzsche ([1886] 1989, II.26) would say, "the rule is more interesting than the exception."
} 
close...election outcomes turn on how these "swing voters" happen to feel when they go to the polls. As Philip Converse [citation omitted] put it, "Not only is the electorate as a whole quite uninformed, but it is the least informed members within the electorate who seem to hold the critical balance of power, in the sense that alternations in governing party depend disproportionately on shifts in their sentiment."

The result is that, from the viewpoint of governmental representativeness and accountability, election outcomes are essentially random choices among the available parties - musical chairs. Elections that "throw the bums out" typically do not produce genuine policy mandates, not even when they are landslides. They simply put a different elite coalition in charge [emphasis added]. This bloodless change of government is a great deal better than bloody revolution, but it is not deliberate policy change. The parties have policy views and they carry them out when in office, but most voters are not listening, or are simply thinking what their party tells them they should be thinking. This is what an honest view of electoral democracy looks like. (Achen and Bartels 2016, 312)

The topic unaddressed by Achen and Bartels is the mechanism by which a particular "elite coalition" emerges from the "musical chairs" electoral process. Marx had an account of how elite consensus emerges, but an adequate account of the emergence of a particular "elite coalition" would no doubt turn on the mechanisms by which control of extant political parties can be seized. On this Achen and Bartels are silent, but it is the really crucial research question suggested by their realism about democracy.

But back to our main topic: given realism about democracies, what does it mean to say, as I said earlier, that some democracies are merely "masquerading" as such, concealing in reality plutocracies or incipient authoritarian societies? The answer, I believe, is, in one sense, rather simple. It means that the tribal loyalties operate in such a way that actual decisions about policy are taken either by (a) economically dominant groups in accord with their interests, not the interests of the tribal groups that support them; or (b) authoritarian groups in accord with their interests, and not the interest of those tribal groups that support them. ${ }^{34}$ The former was true in the Clinton Administration of the 1990s, and the incipient Trump Administration is already beginning to fit both models, with tax cuts for the rich as well as demonization of minorities and immigrants in the name of "jobs" and "national security." How that came to be the case in the United States is the hard question, but beyond the scope of this paper. ${ }^{35}$ But the descriptive generalization still stands.

\footnotetext{
34 The interests of authoritarian elites often track those of economic elites, but not always.

${ }^{35}$ A useful documentation of the fact that it is the case is Gilens and Page (2014). The standard Marxist theory of the state under capitalism - as the committee that organizes the affairs of the ruling class - would have predicted as much. Two peculiar factors in the American case are the huge size of the country, which favors those with resources who can access the mass media, and
} 
So if electoral democracy is, as the realists portray it, a matter of tribal loyalties translating into party identification, and then electing representatives, who may or may not even represent the views of the tribes that elected them, how should that affect our conception of the roles of judges?

\section{A Realistic View of the Judicial Role}

Everywhere judges-consistent with what I dubbed earlier their familiar "Minimal Role" - are expected to apply pre-existing standards, meaning usually "the law," though as judicial oaths of office reveal, they are sometimes expected to do more, and often in terms that are not obviously consistent with the Minimal Role. Whether judges should keep those promises is an open question, but before we get to that, let us look at the promises they are actually asked to make when taking office in a variety of modern legal systems. These promises display some striking ambiguities, and also reveal the extent to which even judicial promises leave much of the judge's role open.

In Serbia, for example, judges take the following (rather typical) oath: "I solemnly swear on my honour that I will perform my duties in compliance with the Constitution and the law, according to the best of my knowledge and ability and in the service of only truth and justice." 36 The promise of Serbian judges embodies the ambiguity in many such promises: namely, between loyalty to the law, and then loyalty to "truth and justice." But how does one serve "truth and justice" if one is supposed to comply with laws that are unjust or contain actual falsehoods? It is unclear from the Serbian oath, though this oath is hardly atypical in this regard.

The German oath, pursuant to the German Judiciary Act, ${ }^{37}$ is similar: "I swear to exercise judicial office in conformity with the Basic Law of the Federal Republic of Germany and with the law, to adjudicate to the best of my knowledge and belief, without distinction of person, and to serve the cause of truth and justice alone-so help me God." German jurists, who perhaps know better than most that God does not exist, are allowed to omit the "so help me God" bit at the end. The German oath also adds the interesting demand, one that is otiose on the Basic Law, namely, adjudication "without distinction of person," but that again perhaps reflects the special history of Germany in the last century. Like the Serbian oath, it poses the puzzle how fealty to false or unjust law is compatible with serving only "the cause of truth and justice."

An Egyptian judge must swear "by God Almighty that I shall adjudicate between people according to justice and respect the laws," ${ }^{38}$ which poses the same

the high level of religiosity, which capitalism usually destroys more effectively than it has in the

U.S. The latter complicates the economic elite story.

${ }^{36}$ Law on Judges, Official Gazette of the Republic of Serbia, No. 116, 2008, Art. 54.

${ }^{37}$ Deutsches Richtergesetz [German Judiciary Act], Apr. 19, 1972, BGBL. I at 713 as amended.

38 See Shahine (2007) for evidence of this oath being administered. 
puzzle about how to resolve conflicts between justice and fealty to the positive law (unless justice is just a different way of saying "fealty to law," in which case it is otiose). Judges in Israel must pledge "allegiance to the State of Israel and its laws" and swear "to dispense true justice, not to pervert the law or to show favor." 39 This promise arguably implies that if "true justice" is at stake, then ignoring positive law would not be a "perversion" of such law, but a requirement. In South Africa, judges of the Constitutional Court and Supreme Court promise to be "faithful to the Republic of South Africa," as well as "uphold and protect the Constitution and the human rights entrenched in it, and will administer justice to all persons alike without fear, favour or prejudice, in accordance with the Constitution and the law." 40 This oath has in it an interesting additional ambiguity: is it the duty of judges to protect actual human rights or only the "human rights entrenched in" the Constitution? The latter is the more natural reading, but at the same time, it would seem an odd oath if it were rewritten to make that explicit ("I promise to uphold and protect the Constitution and only those human rights recognized by it, but other human rights - well, they get no protection"). ${ }^{41}$

Perhaps the most interesting oath in the ones I surveyed is the one from Hungary:

I hereby do solemnly swear that I shall assess the cases entrusted to me in fair proceedings, without bias, conscientiously, solely in accordance with the rules of

\footnotetext{
${ }^{39}$ See State of Israel Judicial Authority (n.d.).

${ }^{40}$ S. Afr. Const., sched. $2 \S 6(2)$ as amended by Sixth Amendment Act of $2001 \S 18$.

${ }^{41}$ South African judges frequently rule on whether or not a particular law or practice is consistent with "human rights," appealing to the principles underlying the Constitution. S v Makwanyane and Another (CCT 3/94), for example, struck down the use of the death penalty as inconsistent with the commitment to human rights enshrined in the South African Constitution. (Thanks to Cora True-Frost for calling this case to my attention.) Indeed, the South African Constitution refers to "human rights" without qualification, even though the requirements of human rights under the South African Constitution are not coextensive with those of international human rights law. S v Makwanyane says this directly, as it notes that international human rights law does not ban the death penalty, but holds that the South African Constitution requires otherwise. As the Court stated: Our Constitution expresses the right to life in an unqualified form, and prescribes the criteria that have to be met for the limitation of entrenched rights, including the prohibition of legislation that negates the essential content of an entrenched right. In dealing with comparative law, we must bear in mind that we are required to construe the South African Constitution, and not an international instrument or the constitution of some foreign country, and that this has to be done with due regard to our legal system, our history and circumstances, and the structure and language of our own Constitution. We can derive assistance from public international law and foreign case law, but we are in no way bound to follow it. SvMakwanyane and Another (CCT 3/94) section 39. http://www.saflii.org/za/cases/ZACC/1995/3.html.
} 
law; in the fulfilment of my duties, I shall be driven by the desire to uphold justice and equity. ${ }^{42}$

In Hungary, judicial fealty is not to the country, its constitution or legal system, but to impartiality in adjudication "in accordance with the rules of law" and to "justice and equity." This would appear to give a Hungarian judge ample grounds for going beyond the positive law-assuming they had the requisite desire "to uphold justice and equity" - something such a desire is likely to require under Viktor Orban, let alone Jobbik, although there is little sign Hungarian judges are fulfilling their promise.

As the preceding examples make plain, judicial oaths leave it uncertain how judges should resolve conflicts between positive law, truth, and justice. But now, with our realist hats on again, we should remember that the idea that promises actually bind has the same status as the idea of "obligation" generally: certainly many people, especially those who have been reading too much Kant, feel very strongly that promises create binding moral obligations. But the promises judges make, as the examples above illustrate, are various and at times vague about the relationship between judicial obligations and obligations to justice and truth. Should one feel that promissory obligations defeat the general "obligations" to do what is just, especially in cases where the promise is ambiguous about how to resolve the conflict between justice and law? Legal philosophers typically note that judges are also human, and insofar as we feel that humans ought to behave morally, then judges should too. From this it follows, as every legal positivist I know believes, that promises to uphold the law notwithstanding, sometimes judges ought to do what is "morally right" even if that is in violation of the Minimal and Minimal-Plus Roles of judges. When we remember what democracy is really like, that judges should sometimes do that should seem less worrisome (though it depends, of course, on the judiciary, a point to which we return below).

The central theoretical constraint in thinking about judicial roles has to do with the nature of law itself, since we would not otherwise know how to interpret the command to apply or follow "the law," so central to the various judicial oaths. There is a superficial if popular view according to which law is created by legislators, and judges are the mere mechanical appliers of the law. Whether the society is authoritarian or democratic, this view is a gross simplification, as all lawyers and scholars know. Even if one agrees that norms are legally valid only in virtue of their source (e.g., legislative or judicial enactment), and even if one agrees that where there is a legal system, there exists Hart's naturalized version of a Kelsenian Grundnorm, namely, a practice of officials of treating certain criteria as obligatory criteria of legal validity, that still does not tell us the role of a judge, even on the assumption that judges should "apply the law." Statements of the law,

\footnotetext{
42 See Opinion on Act CLXII of 2011 on the Legal Status and Remuneration of Judges and Act CLXI of 2011 on the Organisation and Administration of Courts of Hungary, European Commission for Democracy through Law, Op. 66 (Mar. 19, 2012).
} 
whether by legislatures or courts or any other lawmaker, must be interpreted so that their import with respect to particular facts is clear. Every serious scholar who has written about legal interpretation over the last century-from the American Karl Llewellyn to the Englishman H.L.A. Hart to the Italian Riccardo Guastini to the Frenchman Michel Troper, among many others - has recognized that interpretive norms in a given legal system accord judges latitude, perhaps great latitude, in saying what the law is. Even the most fantastical sophist and moralist of the last century's legal philosophy, Ronald Dworkin, admitted that no one may really know what the right interpretation of the law is (though he, of course, believed there was one and he happened to know what it was). Dworkin's main focus was, ironically, the American constitutional order, in which its highest court is rather clearly - to realists-a super-legislature (Leiter 2015c). What that means, of course, is that judicial decisions interpreting the other sources of positive law can be crucial sources of legally valid norms themselves - and not just for the parties before the court, at least in any legal system that treats judicial precedent as a valid source of law.

So what legal constraints are there on interpretation? Here there is little of a general nature we can say, since norms of legal interpretation vary with legal systems just as Hartian rules of recognition do. Since rules of recognition are social rules in Hart's sense-that is, psycho-social artifacts arising from the actual interpretive practices of the judges that they endorse from an internal point of view - it follows that norms of interpretation can evolve and will vary with the nature of the judiciary and its interpretive practices: for example, civil service systems, where judges are promoted by peer evaluation, create more pressure towards adhering to the prevailing interpretive norms, while systems, like the American, which are political, do not. ${ }^{43}$ If there are generalizations available about viable norms of interpretation, I suspect they derive more from sociological facts about how law interacts with society and human interests, and the practical constraints that then emerge on interpretive practices, rather than from any true philosophical thesis about the nature of law. I consider only one example.

In the United States, a small number of judges, and many more legal scholars, have argued that the Constitution should be interpreted according to its "original" meaning. Bear in mind that the U.S. Constitution was written in 1789, though amended in significant part after our Civil War in the 1860s. Originalism in America has come in two varieties. One version is that constitutional provisions should be interpreted in accordance with the intentions of those who wrote the provisions. The other version, popularized especially by the late Justice Antonin Scalia of our Supreme Court, is that constitutional provisions should be interpreted in accordance with the original "public meaning" of the provisions, the latter determined not by historical inquiry into the intentions of framers of the

${ }^{43}$ Cf. Gilmore's (1961) "explanation" of legal realism and Posner (1996) on the American vs. British judiciary. 
provisions, but by old dictionaries and historical evidence about the circumstances and problems to which the provision was responsive. ${ }^{44}$

The first version of originalism famously confronted the problem of identifying meaningful intentions of collective bodies, especially about matters they never could have anticipated..$^{45}$ The second version was also afflicted by disputes about how one fixes the initial "public" meaning. ${ }^{46}$ But there is a deeper practical problem afflicting both versions: the real problem is not that there is never any fact about the original intent or meaning of a constitutional provision (sometimes there is), but that serious commitment to original intentions or meanings will inevitably undermine constitutionalism altogether, that is, the idea that political power should be constrained by a piece of legislation that no one living participated in enacting and that cannot be repealed or overridden in the manner of ordinary legislation. "Originalism" makes for good rhetoric, but usually awful politics, something that all jurists in the U.S. recognize, whether explicitly or not. ${ }^{47}$ Let us call this the Real Problem of Constitutional Interpretation.

The Real Problem is that constitutional restrictions on what current polities want to do always make current polities deeply unhappy. Now we must remember that, given realism about democracy, this is not the same as saying that constitutional restrictions are restrictions on democratic majorities. That is false, since elected officials who might find themselves constrained by a constitution do not represent the moral and political views of current democratic majorities (except sometimes by accident), for the reasons already discussed. That being said, there is a limit to how much political elites and perhaps even voters will tolerate frustration of their

${ }^{44}$ See, e.g. Justice Antonin Scalia's originalist opinion in Crawford v. Washington, 541 U.S. 36 (2004) reinterpreting the "Confrontation Clause" of the U.S. Constiution as prohibiting the admission of certain kinds of "hearsay" statements against criminal defendants, statements that would otherwise have been admissible under traditional exceptions to the rule excluding hearsay. Because Justice Scalia's approach has created so many burdens for prosecutors, the one former prosecutor on the Supreme Court, Justice Sonia Sotomayor, has been doing her best to weaken the rule: e.g., Michigan v. Bryant, 562 U.S. 344 (2011).

${ }^{45}$ See, e.g., Brest (1980). In the U.S., a new originalist literature, inspired by the work of Keith Whittington, tries to dodge this problem by distinguishing "interpretation" (determining the ordinary, communicative meaning of the provision) and "construction" (determining its legal effect). The distinction is dubious, since in every legal jurisdiction I am aware of, there are rules of legal interpretation that make ordinary, communicative meaning irrelevant. (Take the U.S.: is it "cruel and unusual" and thus unconstitutional to execute juveniles? As a matter of ordinary meaning, who knows? But it is clearly unconstitutional now given the rules of legal interpretation in the U.S.) Proponents of the distinction, of course, think this is the way interpretation ought to be pursued, but most of them fail to articulate a normative reason for doing so; an exception is Randy Barnett, who thinks the original Constitution is morally superior from a moral and political point of view. See Barnett (2004). If that were remotely plausible, then this would be a good argument.

${ }^{46}$ See Zlotnick (1999), esp. pp. 1407-1410 and accompanying notes.

${ }^{47}$ There could, of course, be circumstances where originalist rhetoric is the preferred interpretive device of progressives, a point we should not lose sight of. (Thanks to William Hubbard for pressing me on this point.) 
objectives by an old piece of legislation, that is, the constitution. ${ }^{48}$ And constitutions are, as we all know, just old pieces of legislation with special prohibitions on their repeal by later legislators, often a degree of generality about political aspirations, and a certain positive moral valence attached to them. One need not be an historical materialist to recognize that the world changes continuously as its economic and productive power evolves, and that these changes affect the values, aspirations, and goals of human beings and their political associations. ${ }^{49}$ (Historical materialists do have the theoretical advantage of explaining this!) What that means, of course, is that serious originalism, of either variety (intentionalist or public meaning), endangers the idea of constitutionalism, of the attractiveness of being bound by old pieces of legislation. Constitutionalism as an ideal survives only because incremental adjustments to constitutions by courts are possible in every jurisdiction I am aware of, and so the most offensive aspects of being bound by the will of long-dead people-sometimes rather unappealing long-dead people!-are removed or mitigated. Perhaps constitutionalism has no value, though on the limited evidence we have (after all, only the U.S. and Sweden have constitutions that span four centuries), it seems that constitutions may exercise a human welfare-maximizing constraint on current polities.

Canada, the more European-leaning neighbor of my country, is an interesting case study in this regard. The Canadian Charter, or "constitution," was adopted only in 1982, but the courts moved quickly to repudiate the idea that the intentions of its framers controlled its interpretation. In 1985, the Supreme Court of Canada in Re B.C. Motor Vehicle Act ${ }^{50}$ made clear that the intention of the framers did not control how the "principles of fundamental justice" should be interpreted. A bit of realistic context is important. The United States Supreme Court claimed authority for itself to settle the meaning of the U.S. Constitution some two hundred years ago, ${ }^{51}$ a point that could not have been lost on the Canadian High Court. Also not lost on them was the fact that the framers of the 1982 Canadian Charter were quite alive, and would be for a long time. In order not to have its authority usurped, it was important to make clear, and make clear quickly, that having written the Charter, the authors were done. What that Charter meant was now in the hands of the courts and the polity. But this was not simply a "power-grab," but a clear-headed recognition of the fundamental fact of "constitutionalism":

\footnotetext{
${ }^{48}$ In the age of Trump, one might expect that the limit is reached very quickly!

${ }^{49}$ Cf. not only Marx's corpus, but more recently Ian Morris (2015) and, a bit longer ago, Marvin Harris (1974). While Marx treated the level of development of a society's productive powers as a whole as the crucial explanatory variable, Morris (a classical archaeologist) focuses specifically on the degree of energy extraction from nature, while Harris (an anthropologist) looks at short-term material incentives, such as the ability to have enough food to eat in the year ahead. Morris and Harris are, as it were, "micro"-Marxists, accepting the basic Marxist thesis that how people produce the conditions of their material existence determines their beliefs, but filling in the micromechanisms that explain the patterns we find. Harris is better than Morris in this regard, since Harris is more alert to what would motivate individuals to act as they do, while Morris operates largely at the level of striking correlations, without sufficient attention to psychological mechanism.

50 [1985] 2 SCR 486.

${ }^{51}$ Marbury v. Madison, 5 U.S. 137 (1803).
} 
namely, that a polity (e.g., its political elites) will not tolerate being (at least somewhat) bound by its predecessors unless there is substantial room for adjustment. This is why America's most notorious originalist, the late Justice Antonin Scalia, attracted almost no judicial adherents for his radical originalism over nearly forty years. Most American lawyers and judges are tacit realists, whatever their public ideology.

\section{The Roles of Judges in Democracies}

So if we are realistic about democracies and about judges, what conclusions can we draw from the preceding observations? ${ }^{52}$ I am not interested in the banal "obligations" partly captured by the Minimal and Minimal-Plus views. I want to focus only on the key issues, as stated earlier: what are the obligations of judges in determining the existence and meaning of the pre-existing standards, when they have latitude within the rule of recognition about how to determine it; and what are the obligations of judges when the meaning of the pre-existing standards are determinate? Since on a realistic view of the judicial role, it involves inherently moral and political judgment (Leiter 2015c), I see no way to answer these questions about the "obligations" of judges without regard to their moral and political views.

Let me introduce some categories that will help us conceptualize the options. The categories are admittedly crude, but their crudity may highlight what is at stake. I use the terms "progressive," "reactionary" and "status quo" in descriptive senses in what follows, though the terms often have moral valences. "Progressive" may seem the least descriptive of the three, but I use it here in what we can call the descriptive "Hegelian sense." Hegel, a deeply religious philosopher, ${ }^{53}$ thought that the history of humanity was a matter of recognizing (with the help of Hegel's philosophy, of course) God's intentions for His creation. Divine intentions to one side, what was striking, and which Hegel noticed, is that there has been a general tendency in human history of expanding the domain of "freedom." 54 Think only of democratic voting rights in America: first, it was only propertied white men; then men without property, then women, then non-whites, and so on. The history of humanity, for Hegel, is the history of human recognition of God's plan for the expansion of freedom. ${ }^{55}$ Progressive means - as a shorthand for its clearly Hegelian

\footnotetext{
${ }^{52}$ I think the view I defend, below, is not that far away from the view articulated by Judge Posner originally in Posner (1999), though I eschew his terminology about "pragmatism" which conceals more than it explains.

${ }^{53}$ Frederick Beiser's volume on Hegel (2005) in my Routledge Philosophers series makes this pleasingly clear, against the revisionists and apologists. Hegel's religiosity had much to do with the pernicious influence he had on Marx, who despite his own atheism, retained allegiance to nonsense like the teleological structure of history.

${ }^{54}$ Cf. my Meador Lecture (Leiter 2013).

${ }^{55} \mathrm{Hegel}$, rather notoriously, seemed to think this expansion reached its perfection with the Prussian state circa 1820, but that tells us more about the parochialism of philosophy than about freedom.
} 
background ${ }^{56}$ - increasing the range of people who enjoy freedom and/or increasing the kind of freedom enjoyed. (Many "progressives," of course, think the range should extend to non-human animals and even non-animal nature. Other "progressives" - I think I am one-are more skeptical.) The boundaries of such freedom are contestable, but the basic pattern is crystal clear: more and more humans (and maybe even non-humans) are entitled to the same moral concern, and the same moral rights, as others. This is the central ideology of postEnlightenment modernity - shared by Kant and Marx, as well as Rawls and Hayek - and one opposed only by Nazis, fascists, reactionaries, and religious traditionalists of all stripes. ${ }^{57}$ One might, of course, insist that the real metric of progress is improvement in "well-being," but that is compatible with the point just made: freedom, in the relevant sense here, stands in a constitutive relationship with "well-being" - you can not be well-off unless free, and vice versa - so for ease of discussion I will speak strictly in the former terms.

The other two terms again have descriptive content, though also normative connotations, depending on who is using the terms. Those who favor the "status quo" are those who favor, obviously, the way things are. This can have a pejorative connotation when the status quo isn't very attractive by the lights of the speaker, but it need not have such a connotation, since sometimes the status quo is morally preferable to the available alternatives, even by the speaker's lights. Those who are "reactionary" would like to return society to an earlier state of affairs, especially in terms of the legal and political status of citizens: a reactionary opposes the expansion of the freedom the progressive favors.

It is important to note that many debates between so-called "conservatives" and "liberals" are not necessarily debates between reactionaries and progressives in my sense, but rather intramural debates between progressives in the Hegelian sense, that is, those who disagree either about the means or about the extension of the relevant concepts of freedom. This is one reason that in American scholarly discourse it seems perplexing to put libertarians on the right ("the conservatives"). Libertarians contest the kind of freedom that modernity should progress towards, and so are often at odds with actual reactionaries. From the left progressive point of view, libertarians are reactionaries because of their naivete about how so-called "economic freedom" operates in practice, but that, of course, is precisely what is disputed. (To be sure, to the extent Hegel is right about the progressive tendency of modernity, we should hardly be surprised to find actual reactionaries trying to obscure their position by framing it, for rhetorical reasons, in "progressive" terms.)

In talking about the roles of judges in democracies, I assume-without argument, since there is no useful argument that can be given - that judges should

\footnotetext{
${ }^{56}$ I see no way to understand talk of "progress" except against the Hegelian/Christian background and its normative assumptions.

${ }^{57}$ On "traditionalism," see the $20^{\text {th }}$-century Italian fascist philosopher Julius Evola, cited favorably by Trump's former advisor Stephen Bannon.
} 
facilitate progress, rather than protect the status quo unreflectively or move us backwards. If the reader grants me that assumption, then the question about the roles of judges in democracies becomes clearer, though it has to be relativized to the background facts about the judiciary and the democracy. Here are, I believe, the relevant parameters.

A Progressive Judiciary is one that wants to expand freedom, and so exercises its interpretive latitude in service of that end. ${ }^{58}$ A Status Quo Judiciary takes its promise to uphold the positive law very seriously, and even where there is interpretive latitude, interprets it in favor of the status quo. A Reactionary Judiciary is anti-progressive, looking to restrict freedom to the elite classes or races or sects who had enjoyed its exclusive prerogatives in the past.

A Progressive Democracy is one in which tribal loyalties have converged upon legislation that expands freedom. Canada and Germany are arguably examples today. A Middling Democracy is one in which tribal loyalties entrench a status quo that is neither progressive nor reactionary. The United States is arguably an example today, though perhaps we are about to enter a reactionary era. Finally, a Reactionary Democracy is one in which the tribal loyalties have converged upon legislation that restricts freedom, aiming to bestow its benefits only on select elites or groups. Hungary and Poland are arguably examples today.

Finally, we need some way of characterizing the effect of judicial invalidation (or reinterpretation) of legislation in different systems. ${ }^{59}$ Let us call a Judge-Centered System one in which judicial decisions invalidating legislation are generally accepted and are absorbed with little resistance by political elites and popular constituencies. Let us call a Legislature-Centered System one in which legislation has prima facie popular and elite legitimacy, and judicial invalidation of such legislation is typically met with skepticism or resistance by elites and perhaps popular constituencies. Mixed Systems are ones in which judicial invalidation of legislation sometimes looks like a Judge-Centered system, sometimes like a Legislature-Centered system.

Given these rough categorizations, here is how I suggest we think of the "obligations" of judges in contemporary democracies.

Progressive Judiciaries in Progressive Democracies should exercise minimal interpretive latitude with respect to positive law, and should honor the Minimal Role of judges, scrupulously in Legislature-Centered Systems, since this will both promote progressive ends and honor public expectations and sustain the

\footnotetext{
${ }^{58}$ Note that I assume that a progressive judiciary can only promote freedom and equality within the constraints of its institutional role. Other progressives will, of course, pursue progressive ends within the parameters of their roles. (Thanks to Omri Ben-Shahar for pressing me on this issue.)

59 Of course, there are legal systems in which courts officially lack the power to invalidate legislation-Britain, with its doctrine of parliamentary sovereignty may be the most important case, though there is a clear tradition of parliament revisiting legislation when the courts find an "inconsistency" with fundamental rights.
} 
legitimacy of judicial review. Progressive Judiciaries in Middling Democracies should exercise their interpretive latitude in order to move the law in a progressive direction-aggressively in a Judge-Centered System, less aggressively in a Legislature-Centered system. Progressive Judiciaries in Reactionary Democracies should exercise their interpretive latitude aggressively, even in a LegislatureCentered system. The loss of legitimacy for the judiciary in aggressive judicial review is worth the risk given the morally defective character of a Reactionary Democracy.

Now the preceding admittedly simplifies how a progressive judiciary should think about its obligations, especially in Middling and Reactionary Democracies. A judge who thinks she has an obligation to exercise interpretive latitude in the service of progress (perhaps even to disregard settled law in the service of progress) must also take into account the ramifications of doing so-for example, the likelihood of provoking a reactionary legislature to revisit a question where the judge has ruled in a different direction. The pursuit of progress must of course be strategic, within the parameters in which an agent of progress can operate. A progressive judge who disregards the "backlash" effect of her decisions is not a reliable friend of progress.

With that important caveat in mind, we can proceed to the other cases. A Status Quo Judiciary should honor the positive law, and exercise minimal interpretive latitude in a Progressive Democracy, whether its culture is Legislature-Centered or Judge-Centered. In a Middling Democracy, a Status Quo Judiciary in a Legislature-Centered System, should probably act similarly, since it is unlikely to exercise interpretive latitude for progressive ends, and even if it did so, little good would likely result. If the Middling Democracy is Judge-Centered, then a Status Quo Judiciary should exercise its interpretive freedom in progressive directions, to the extent it is able to do so. In a Reactionary Democracy, the obligation of a Status Quo Judiciary is to try to be Progressive!

You can infer from the preceding how my account of obligations will go in the other cases. But let me address one case explicitly, namely, that of Reactionary Judiciaries in Reactionary Democracies. These judges have only one obligation in my view: to resign their position or, equally unlikely, reform their moral views.

The preceding has focused only on the judicial role vis-à-vis legislation, but a similar set of recommendations could be generated for the judicial role in interpreting prior court decisions or constitutional provisions or the edicts of administrative agencies. ${ }^{60}$ A Progressive Judiciary will generally produce progressive precedents, though judiciaries are not univocal and there may be outliers of course. In that case Progressive Judges should utilize their interpretive latitude in much the same ways as they do with respect to non-progressive legislation. Here the risks are likely to be different than in the legislation case: that

${ }^{60}$ Thanks to Jennifer Nou for pressing me on this point. 
is, the risk is not provoking legislative backlash, but judicial backlash from less progressive colleagues. Once again, the same kinds of considerations apply as in the legislation case: progressive lower courts need to be mindful of their status quo or reactionary higher courts, and so on. But the basic idea is the same: progressive judges ought to pursue, strategically, progressive outcomes, with due attention to context and ultimate outcome. ${ }^{61}$

Now to some all the preceding will sound too facile: surely, the obligations of judges should not depend on the quality of their moral views, or the moral quality of the legislation they must review? It is true that the question is typically approached without regard to these kinds of distinctions, but such an approach is unrealistic both about the judicial role and about democracies in my view. Judges should generally honor their Minimal Role, but not always. And their Minimal Role affords them considerable latitude, and how that latitude should be utilized has to depend on the quality of the judges, i.e., the quality of their moral and political judgment. Insofar as moral and political judgment is essential to exercise of the judicial role, especially at the highest levels of appellate review, and insofar as democracies differ in their moral and political character (as they obviously do), I see no way of discussing what judges should do without regard to their moral and political judgment and the nature of the democracy in which they serve.

To another kind of skeptic this way of thinking about the judicial role will seem to presuppose that we really know what kinds of decisions protect and expand freedom and well-being. Clearly we do not know with certainty what state of affairs would actually maximize real human freedom and well-being. But within the horizons of actual judgment, we often do know, even allowing that there will be contested cases. Decisions that protect the freedom of individual choice, within the limits set by some reasonable understanding of the Millian Harm Principle, and decisions which support social-economic policies that protect

\footnotetext{
${ }^{61}$ A nice example of strategic thinking by progressive judges comes from cases in Ohio in the 1840s and 1850s, in which judges were confronted with the question of whether to return escaped slaves to the slave-holding American South. Considerations of comity first dominated, but by the $1850 \mathrm{~s}$ receded. Compare Birney v. State, 8 Ohio 230, 238 (Ohio 1837) (holding the indictment for harboring an escaped slave defective for not charging scienter, thus not reaching the question whether a slave who escaped while in transit through Ohio was free ("it thus becomes unnecessary to decide upon the other points, ... of a character too important in their bearing upon the whole country to be adjudicated upon without necessity")), and State v. Hoppess, 2 West.L.J. 279 (Ohio 1845) (holding a slave escaped from a boat docked to the Ohio shore of the Ohio River was a fugitive and thus subject to recaption under federal law, but noting that a slave brought voluntarily into Ohio would be emancipated), with Anderson v. Poindexter, 6 Ohio St. 622, 630-631 (Ohio 1856) ("There has never been a period during our state government, when a slave could for one single moment, by the consent and act of its owner, be placed and continued in bondage here. ... Kentucky can not, by the law of comity, demand of this state an abrogation of its constitution and municipal laws, to promote any of its own peculiar institutions ...."). For a thorough account of the Ohio slave transit and fugitive slave cases of this period, see Finkelman (1981, chap. 6). (Thanks to Todd Henderson for calling my attention to these cases.)
} 
people from misfortune and encourage productive activity within capitalist relations of production (the current benchmark, of course) are good decisions. All complications to one side, the preceding basically describes the neoliberal consensus of the past half-century. ${ }^{62}$ There may be hard cases, of course, where it is unclear, and so the obligation of judges will be less clear. But the only theory of judicial obligation that avoids such problems is one that would be morally ridiculous (e.g., judges should defer to whatever the legislature or executive says, regardless).

In any case, the genuinely hard cases, from a progressive point of view, are few and far between. The Affordable Care Act honored the Hegelian impulse to maximize freedom by extending access to healthcare-essential to well-beingand the U.S. Supreme Court correctly upheld it, ${ }^{63}$ albeit in a way designed to appease the ideological deformities of the current moment in American political life. If there is an argument against the ACA, it has to be that its means were inadequate to its objective - and to the extent they were, it seems to have been because of the need for political compromise in its passage. Legalizing same-sex marriage ${ }^{64}$ obviously expanded freedom, with the arguments against it turning on religious and metaphysical fantasies about the alleged "nature" of marriage ${ }^{65}$ that bore no relation to the role of marital union in the capitalist West. American free speech doctrine is a notorious moral catastrophe, ${ }^{66}$ shielding Nazi sociopaths and pathological defamers, in a way no other democracy does. That the U.S. Supreme Court has gone so wrong in the latter cases, as it has on its campaign financing decisions ${ }^{67}$ is easily explicable by the pathologies of American plutocracy (people with money to burn that amplifies their voice over other citizens think such amplification is central to free speech) ${ }^{68}$ But the important point is that these kinds of decisions are pretty obviously wrong from the stand point of progressive judges. The disagreements on these issues between progressive judges and others who are not explicitly reactionaries are disputes about the empirical facts. If the facts were otherwise, progressive judges should yield, of course.

In this regard, I should emphasize that my proposed template for thinking about judicial obligations is easily applicable as well by jurists and theorists who dispute the empirical facts. A libertarian-that is, someone who disputes the extension of "freedom" and especially the facts about state regimes that maximize it-can accept the preceding framework, but maintain that, for example, the ACA

\footnotetext{
62 The neoliberal consensus may be wholly wrong (as I think it is), in which case interpret "progressive" etc. accordingly.

${ }^{63}$ National Federation of Independent Business v. Sebelius, 567 U.S. 519 (2012).

${ }^{64}$ Obergefell v. Hodges, 135 S.Ct. 2584 (2015).

${ }^{65}$ See, e.g., Girgis, Anderson, and George (2012).

${ }^{66}$ For doubts, see Waldron (2012) and Leiter (2016b) (2013 Julius Stone Address in Jurisprudence).

${ }^{67}$ See, e.g., Citizens United v. Federal Election Commission, 558 U.S. 310 (2010).

${ }^{68}$ Cf. Leiter (2016b).
} 
should have been invalidated, since it did not really maximize human well-being. On this interpretation, invalidation of the ACA is the "progressive" decision, because of a dispute about the nature of freedom and facts about the legislation in application. This view is wrong, but at least we have now located the dispute in the right place, rather than in nonsense about the act/omission distinction as the U.S. Supreme Court did. So, too, an actual reactionary, one who does not think human freedom and well-being without regard to rank or status matters, can also think the ACA should be invalidated, since maximizing the freedom of all human beings has no value- not because such a decision is progressive, but because a reactionary decision is preferable. Obviously, in both cases, it is dubious that the interpretive latitude afforded judges, even in America, would have licensed that outcome on those reasons, but that might not matter if judges at the highest appellate levels choose outcomes that are legally permissible on the basis of their moral and political views, and the boundaries of permissibility are fluid and wide. ${ }^{69}$

In short, I think it is a virtue of my account that it locates the dispute at the right place: not about some putatively "generic" judicial obligation, but at the level of substantive disputes about the facts about how particular policies affect human beings. Counting against my approach, however, is the fiction that judges are morally and politically neutral appliers of the law. I do not want to deny that this fiction is taken very seriously in most societies that honor Democratic Values and that it may turn out to be of crucial importance to human freedom and well-being in some circumstances: realism demands as much. But I am not aware of a legal system that has really tested the relevant hypothesis about the fiction. In that system, the polity would actually understand that pre-existing legal standards can never be adequate to the array of problems that courts are asked to address and would, with H.L.A. Hart, renounce the desire for it to be otherwise:

[W]e should not cherish, even as an ideal, the conception of a rule so detailed that the question whether it applied or not to a particular case was always settled in advance, and never involved, at the point of actual application, a fresh choice between open alternatives....[T] he reason is that necessity for such choice is thrust upon us because we are men, not gods. It is a feature of the human predicament (and so of the legislative one) that we labour under two connected handicaps whenever we seek to regulate, unambiguously and in advance, some sphere of conduct by means of general standards to be used without further official direction on particular occasions. The first handicap is our relative ignorance of fact: the second is our relative indeterminacy of aim....[H]uman legislators can have no such knowledge of all the possible combinations of circumstances which the future may bring. This inability to anticipate brings with it a relative indeterminacy of aim. When we are bold enough to frame some general rule of conduct (e.g. a rule

${ }^{69} \mathrm{I}$ am skeptical they are wide enough for the reactionary, but if, following Karl Llewellyn, the boundaries of legitimate interpretation are defined by a sociological fact-current opinion among lawyers and jurists - then we can hardly be confident. 
that no vehicle may be taken into the park), the language used in this context fixes necessary conditions which anything must satisfy if it is to be within its scope, and certain clear examples of what is certainly within its scope may be present to our minds. They are the paradigm, clear cases (the motor-car, the bus, the motorcycle)....We have initially settled the question that peace and quiet in the park is to be maintained at the cost, at any rate, of the exclusion of these things....[But] [w] e have not settled, because we have not anticipated, the question which will be raised by the unenvisaged case when it occurs....[W]hen [it]...does arise, we confront the issues at stake and can then settle the question by choosing between the competing interests in the way which best satisfies us... (Hart [1961] 2012, 128129)

If there were a legal system that embraced Hart's realism, and then produced catastrophic results for human well-being, we should all pause. We can put the point more starkly: if the fiction is really essential to maximizing human wellbeing, then this paper should be suppressed. But if the fiction is what I and Hart suspect it is, and recognizing it as such would be salutary, then our public discourse about judges in democracies must change accordingly.

\section{REFERENCES}

Achen, Christopher H., and Larry M. Bartels. 2016. Democracy for Realists: Why Elections Do Not Produce Responsive Government. Princeton: Princeton University Press.

Alexander, Michelle. 2012. The New Jim Crow: Mass Incarceration in the Age of Colorblindness. New York: The New Press.

Barnett, Randy E. 2004. Restoring the Lost Constitution: The Presumption of Liberty. Princeton: Princeton University Press.

Beiser, Frederick. 2005. Hegel. New York: Routledge.

Bickel, Alexander M. 1962. The Least Dangerous Branch: The Supreme Court at the Bar of Politics. New York: The Bobbs-Merrill Company, Inc.

Bositis, David A. Blacks and the 2012 Democratic National Convention. Joint Center for Political and Economic Studies.

https://jointcenter.org/sites/default/files/Blacks\%20and\%20the\%202012\%20Democ ratic\%20National\%20Convention.pdf. Accessed 7 January 2019. 
Brest, Paul. 1980. The Misconceived Quest for the Original Understanding. Boston University Law Review 60: 204-238.

Bump, Philip. 2016. Donald Trump got Reagan-like support from union households. Washington Post, November 10.

https://www.washingtonpost.com/news/the-fix/wp/2016/11/10/donald-trumpgot-reagan-like-support-from-union-households/?utm term=.201cdd53fd28.

Cohn, Nate. 2016. How the Obama Coalition Crumbled, Leaving an Opening for Trump. New York Times, December 23.

http://www.nytimes.com/2016/12/23/upshot/how-the-obama-coalition-crumbledleaving-an-opening-for-trump.html.

Cohn, Nate. 2017. The Obama-Trump Voters Are Real. Here's What They Think. New York Times, August 15. https://www.nytimes.com/2017/08/15/upshot/theobama-trump-voters-are-real-heres-what-they-think.html.

Colquhoun, David. 2014. An investigation of the false discovery rate and the misinterpretation of $p$-values. Royal Society Open Science 1, no. 3 (November). doi: 10.1098/rsos.140216.

Easterbrook, Frank H. 1983. Statutes' Domains. University of Chicago Law Review 50, no. 2 (Spring): 533-552.

Easterbrook, Frank H. 1994. Text, History, and Structure in Statutory Interpretation. Harvard Journal of Law and Public Policy 17, no. 1 (Winter): 61-70. Ekins, Richard. 2012. The Nature of Legislative Intent. Oxford: Oxford University Press.

Finkelman, Paul. 1981. An Imperfect Union: Slavery, Federalism, and Comity. Chapel Hill: The University of North Carolina Press.

Fowler, Anthony, and Andrew B. Hall. 2018. Do Shark Attacks Influence Presidential Elections? Reassessing a Prominent Finding on Voter Competence. The Journal of Politics 80, no. 4 (October): 1423-1437. doi: 10.1086/699244.

Gardiner, Stephen M., and David A. Weisbach. 2016. Debating Climate Ethics. Oxford: Oxford University Press. 
Geuss, Raymond. 2008. Philosophy and Real Politics. Princeton: Princeton University Press.

Gilens, Martin, and Benjamin I. Page. 2014. Testing Theories of American Politics: Elites, Interest Groups, and Average Citizens. Perspectives on Politics 12, no. 3 (September): 564-581. doi: 10.1017/S1537592714001595.

Gilmore, Grant. 1961. Legal Realism: Its Cause and Cure. Yale Law Journal 70, no. 7 (June): 1037-1048.

Girgis, Sherif, Ryan T. Anderson, and Robert P. George. 2012. What Is Marriage? Man and Woman: A Defense. New York: Encounter Books.

Green, Leslie. 2016. Law and the Role of a Judge. In Legal, Moral, and Metaphysical Truths: The Philosophy of Michael S. Moore, ed. Kimberly Kessler

Ferzan and Stephen J. Morse, 323-341. Oxford: Oxford University Press. Harris, Marvin. 1974. Cows, Pigs, Wars and Witches: The Riddles of Culture. New York: Random House.

Hart, H.L.A. (1961) 2012. The Concept of Law, 3rd ed. Oxford: Oxford University Press.

Jessee, Stephen A. 2009. Spatial Voting in the 2004 Presidential Election. American Political Science Review 103, no. 1 (February): 59-81. doi: 10.1017/S000305540909008X.

Kinder, Donald R., and Nathan P. Kalmoe. 2017. Neither Liberal nor Conservative: Ideological Innocence in the American Public. Chicago: University of Chicago Press.

Leiter, Brian. 2001. Moral Facts and Best Explanations. Social Philosophy E Policy 18, no. 2 (Summer): 79-101. doi: 10.1017/S0265052500002910.

Leiter, Brian. 2012. In Praise of Realism (and Against "Nonsense" Jurisprudence). Georgetown Law Journal 100, no. 3 (March): 865-893.

Leiter, Brian. 2013. The Boundaries of the Moral (and Legal) Community. Alabama Law Review 64, no. 3: 511-531. 
Leiter, Brian. 2015a. Normativity for Naturalists. Philosophical Issues: A Supplement to Noûs 25, no. 1 (October): 64-79. doi: 10.1111/phis.12046. Leiter, Brian. 2015b. Why Marxism Still Does Not Need Normative Theory. Analyse und Kritik 37, no. 1-2 (November): 23-50. doi: 10.1515/auk-2015-1-204.

Leiter, Brian. 2015c. Constitutional Law, Moral Judgment, and the Supreme Court as Super-Legislature. Hastings Law Journal 66, no. 6 (August): 1601-1616.

Leiter, Brian. 2016a. The Paradoxes of Public Philosophy. Indian Journal of Legal Theory 1, no. 1 (May): 51-64.

Leiter, Brian. 2016b. The Case Against Free Speech. Sydney Law Review 38, no. 4 (December): 407-439.

Leiter, Brian. 2018. Legal Positivism about the Artifact Law: A Retrospective Assessment. In Law as an Artifact, ed. Luka Burazin, Kenneth Einar Himma, and Corrado Roversi, 3-28. Oxford: Oxford University Press.

Leiter, Brian. 2019. Realism and Moralism in Political Thought. In Post-Truth, Philosophy and Law, ed. T. Andina and A. Condell. London: Routledge.

Moore, Michael. 2016. Michael Moore in TrumpLand. Directed by Michael Moore. Produced by Dog Eat Dog Films and IMG Films.

Morris, Ian. 2015. Forages, Farmers, and Fossil Fuels: How Human Values Evolve. Princeton: Princeton University Press.

Nietzsche, Friedrich. (1883) 1976. Thus Spoke Zarathustra. In The Portable Nietzsche, trans. Walter Kaufmann. New York: Penguin Books.

Nietzsche, Friedrich. (1886) 1989. Beyond Good and Evil: Prelude to a Philosophy of the Future. Trans. Walter Kaufmann. New York: Vintage Books.

Pauer-Studer, Herlinde, and J. David Velleman. 2015. Konrad Morgen: The Conscience of a Nazi Judge. London: Palgrave Macmillan.

Posner, Richard A. 1996. Law and Legal Theory in England and America. Oxford: Oxford University Press. 
Posner, Richard A. 1999. The Problematics of Moral and Legal Theory. Cambridge, Mass.: Harvard University Press.

Posner, Richard A. 2008. How Judges Think. Cambridge, Mass.: Harvard University Press.

Rossi, Enzo, and Matt Sleat. 2014. Realism in Normative Political Theory. Philosophy Compass 9, no. 10 (October): 689-701. doi: 10.1111/phc3.12148.

Schattschneider, E.E. 1960. The Semisovereign People: A Realist's View of Democracy in America. New York: Holt, Rinehart and Winston.

Shahine, Alaa. 2007. Egypt women sworn in as judges despite opposition. Reuters, April 10. http://uk.reuters.com/article/uk-egypt-women-judgesidUKL1047186020070410. Accessed 3 January 2019.

State of Israel Judicial Authority. n.d. The Judges: Declaration of Allegiance. http://elyon1.court.gov.il/eng/system/index.html. Accessed 27 January 2019.

Stevenson, Charles L. 1944. Ethics and Language. New Haven: Yale University Press.

Waldron, Jeremy. 2012. The Harm in Hate Speech. Cambridge, Mass.: Harvard University Press.

Weigel, David. 2016. How voters who heavily supported Obama switched over to Trump. Washington Post, November 10.

https://www.washingtonpost.com/politics/how-voters-who-heavily-supportedobama-switched-over-to-trump/2016/11/10/65019658-a77a-11e6-ba59a7d93165c6d4 story.html?utm term $=.92 \mathrm{c} 3 \mathrm{dd} 91729 \mathrm{f}$.

Williams, Bernard. 2005. Realism and Moralism in Political Theory. In In the Beginning was the Deed: Realism and Moralism in Political Argument, ed. Geoffrey Hawthorn, 1-17. Princeton: Princeton University Press.

Zlotnick, David M. 1999. Justice Scalia and His Critics: An Exploration of Scalia's Fidelity to His Constitutional Methodology. Emory Law Journal 48, no. 4 (Fall): 1377-1429. 